\title{
Czym jest, czym (jeszcze) mogłaby być "geopoetyka"?
}

Andrzej Niewiadomski

TEKSTY DRUGIE 2018, NR 5, S. 88-106

DOI: $10.18318 /$ td.2018.5.5

eopoetyka jako „orientacja badawcza” wciąż jest na polskim gruncie zjawiskiem nowym. Jak niemal wszystkie szkoły lektury, dominujące pośród współczesnych dyskursów filologicznych przekształcających się stopniowo w dyskursy kulturowe, stanowi rezultat serii "zwrotów" dokonujących się w przestrzeni zachodniej humanistyki, począwszy mniej więcej od ósmej dekady minionego wieku i usankcjonowanych na przełomie wieków. Wskazywano, co prawda, na nieliczne, rodzime prolegomena do geopoetyki, ale - po serii artykułów różnych badaczy, publikowanych na przestrzeni mniej więcej piętnastu lat ${ }^{1}$ - dopiero książki Elżbiety Rybickiej² czy

\section{Andrzej}

Niewiadomski -

dr hab., Kierownik

Zakładu Literatury

Polskiej XX i XXI wieku

UMCS. Redaktor

Naczelny "Artes

Humanae." Ostatnio opublikował: Jeden jest zawsze ostrzem. Inna nowoczesność

Zygmunta Haupta (2015). Kontakt: and. niewiad@poczta. umcs.lublin.pl

1 Myślę o pracach Elżbiety Konończuk, Magdaleny Marszałek, Macieja Dajnowskiego, Małgorzaty Czermińskiej, Magdaleny Mikołajczak. Do niektórych z nich będę odwoływał się w trakcie wywodu.

2 E. Rybicka Geopoetyka. Przestrzeń i miejsce we współczesnych teoriach i praktykach literackich, Universitas, Kraków 2014. Cytaty oznaczam w tekście skrótem GP i numerem strony. 
Anny Kronenberg ${ }^{3}$, a także tomy zbiorowe $\mathrm{z}$ cyklu Nowy regionalizm w badaniach literackich ${ }^{4}$ stały się próbą zebrania rozmaitych (głównie mających swoje korzenie w humanistyce zachodniej) inspiracji, zarysowania pola, w obrębie którego funkcjonuje geopoetyka, wstępnego uporządkowania jej odmian, zdefiniowania na własny użytek kluczowego terminu i wskazania perspektyw jej rozwoju. Czy w związku z tym możemy mówić o sytuacji, w której niknie większość wątpliwości dotyczących statusu owej dziedziny, jej prawomocności i przydatności w kręgu refleksji stricte literaturoznawczej?

Tak postawione pytanie od razu wprawia badacza w stan konfuzji, bowiem geopetyka, pomijając doraźne jej aplikacje w lekturze tekstów literackich, wykorzystujące "modny” termin przy zachowaniu zwyczajowych trybów interpretacji nakierowanej na „problematykę związaną z reprezentacją przestrzeni geograficznych w literaturze" (GP, 9-10), nie chce i nie zamierza mieścić się w obrębie tego typu refleksji. Jej „przygody” mogą być doskonałą ilustracją wszystkich problemów związanych z przyjęciem „emancypacyjnego" względem stanowisk preferujących autonomię literatury punktu widzenia, uwikłanego we wspomniane zwroty i rozpraszającego wysiłek badawczy w przestrzeni rozmaitych mikrodyscyplin, a także być szczegółowym pretekstem do snucia refleksji na temat szans i zagrożeń związanych z uprawianiem nowej humanistyki ${ }^{5}$.

Można już wskazać dwa zasadnicze stanowiska badawcze ugruntowujące rozbieżne rozumienia terminu i skłaniające ku odmiennym - choć niezupełnie rozmijającym się - praktykom interpretacyjnym. Przy czym nie są one równoprawne, jeśli idzie o skalę zainteresowań i różnorodność uruchamianych narzędzi, bowiem pierwsze z nich eksponuje przede wszystkim „źródłowe" inspiracje, związane z pisarstwem i działalnością twórcy interesującego nas terminu, Kennetha White'a. Stanowisko to wiąże się z postrzeganiem

3 A. Kronenberg Geopoetyka. Zwiq̨zki literatury i środowiska, Wydawnictwo UŁ, Łódź 2014. Cytaty oznaczam w tekście skrótem GŚ i numerem strony.

4 Zob. Nowy regionalizm. Badawczy rekonesans i zarys perspektyw, red. M. Mikołajczak, E. Rybicka, Universitas, Kraków 2012; Geografia wyobrażona regionu. Literackie figury przestrzeni, red. D. Kalinowski, M. Mikołajczak, A. Kuik-Kalinowska, Universitas, Kraków 2014; Centra-peryferie w literaturze polskiej XX i XXI wieku, red. W. Browarny, E. Rybicka, D. Lisak-Gębala, Univeristas, Kraków 2015.

5 Dobry kontekst dla tych rozważań stanowią dwa teksty dotyczące takich szans i zagrożeń: ostrożnie akceptatywny (R. Nycz Nowa humanistyka w Polsce: kilka bardzo subiektywnych obserwacji, koniektur, refutacji, „Teksty Drugie” 2017 nr 1) i ostrożnie sceptyczny (J. Święch Polityka profesjonalizmu, czyli nowa humanistyka, "Akcent” $2017 \mathrm{nr} 3$ ). 
refleksji literaturoznawczej jako części „zwrotu ekologicznego”.Jak pisze Anna Kronenberg: „Na gruncie badań literackich zwrot ekologiczny dotyczy zagadnienia związków literatury i środowiska. Natomiast zwrot topograficzny dotyczy literackiej geopolityki i topografii, związków literatury, geografii, historii i polityki" (GŚ, 33). Co ciekawe, autorka apelująca o powrót do „źródłowego" rozumienia geopoetyki jako „relacji człowieka z Ziemią” i o dokładne przyswojenie na gruncie polskim koncepcji White'a, sygnalizuje, że taka orientacja stanowiłaby „dopełnienie" $i$, uzupełnienie" dominujących obecnie tendencji, a jednocześnie pisze o „wyodrębnieniu” zwrotu ekologicznego i o działaniach, które mogłyby „zapobiec dalszemu myleniu geopoetyki z literacką geopolityką/topografią" (GŚ, 40).

W tym kontekście mogłoby się wydawać, że mocno rozbudowana i uzasadniona propozycja Elżbiety Rybickiej (korzystającej z wielu inspiracji obcych i polskich, zaś myślenie White'a widzącej w kontekście zamierzeń utopijnych) proponuje nam lądowanie na stabilnym gruncie nieco zmodyfikowanych w stosunku do XX-wiecznych założeń praktyk interpretacyjnych. Ale i w tym przypadku podkreśla się, że literatura nie jest pojmowana tylko jako „ergon, finalny wytwór poiesis, ale jako zjawisko żyjące w cyrkulacji, w obiegu kulturowym, w praktykach podejmowanych przez czytelników" (GP, 10).W gruncie rzeczy nie sama literatura interesuje badaczy idących śladem tej autorki, lecz pozycja literatury jako jednego z elementów „sieci” działań konstytuujących rozumienie rzeczywistości przez pryzmat kategorii przestrzennych i „miejsca” i tak też został przez nią wyznaczony teren badań: „Geopoetykę chciałabym wstępnie zdefiniować jako orientację badawczą, która zmierza w stronę kompleksowego, wieloaspektowego - choć powiem ostrożnie - jednak nie całościowego projektu analizowania i interpretowania interakcji (w tym także cyrkulacji) pomiędzy twórczością literacką i praktykami kulturowymi z nią związanymi a przestrzenią geograficzną" (GP, 92). Jak łatwo zauważyć, nie tylko geografia wchodzi tu w grę, lecz także wspomniane "praktyki kulturowe” neutralizujące czy też od dawna (w aspekcie kulturowej teorii literatury) stawiające w podejrzanym świetle swobodę autonomicznych aktów twórczych.

W obu tych przypadkach mamy do czynienia z symbolicznym początkiem. W roku 1978 ukazuje się artykuł Janusza Sławińskiego Przestrzeń w literaturze: elementarne rozróżnienia i wstępne oczywistości. W tym samym roku Andrzej Borowski publikuje artykuł $O$ przestrzeni literatury, który - z perspektywy czasu - wydaje się wytyczać drogę takiemu rozumieniu zjawisk przestrzennych, jakie reprezentuje badaczka i jakie dziś przeważa, rozumieniu odchodzącemu od ujęć ergocentrycznych. W roku 1978 pojawia się też termin "geopetyka" 
w pisarstwie Kennetha Withe'a i takie podejście również jest dalekie - co oczywiste - od akcentowania autonomii tekstu literackiego, dziś zaś inspiracja ta funkcjonuje w obrębie ekokrytyki. Można więc mówić, mimo że geopoetyka jest, według Rybickiej, pojęciem wędrującym, o wstępnej stabilizacji znaczeń terminu na rodzimym gruncie, z tendencją dominującą i nurtem pobocznym.

Jakie wobec takiego stanu rzeczy kłopoty i niebezpieczeństwa wiążą się z przyjęciem uwolnionego od strukturalistycznych (i - w pewnym sensie - poststrukturalistycznych ${ }^{6}$ ) wykładni "geopetyckiego" punktu widzenia? Pierwszą kwestią, jaką w tym kontekście należałoby się zająć, jest sprawa „wędrownych" umocowań geopoetyki. Mimo że w każdym ze wspomnianych ujęć zakreślono obszar, który staje się polem badawczych zainteresowań, to zagadnienie "metody” może budzić różnorakie wątpliwości. Rzecz nie w wielości znaczeń terminu, te bowiem można wyszczególnić i odseparować, lecz w nakładaniu się na siebie trybów analizy i twórczej praktyki pisarskiej. Niemal wszyscy badacze podejmujący się zakreślenia ram funkcjonowania geopoetyki zwracają uwagę na wieloaspektowość pojęcia, które niekoniecznie musi sygnalizować obecność scjentystycznego dystansu (geopetyka jest - z założenia - refleksją radykalnie zrelatywizowaną ${ }^{7}$, a to stanowi tyleż zaletę, ile jedno z jej kluczowych ograniczeń). Oksana Weretiuk, próbując zestawić znaczenia interesującego nas terminu, wyróżniła sześć kategorii, spośród których tylko jedna odnosi się do praktyki interpretacyjnej sensu stricto, pozostałe stanowią ogólną „refleksję teoretyczną", ,ruch intelektualny”, „sposób artystycznego postrzegania świata i tworzenia dzieł sztuki”, ,dzieła” czy „działalność dydaktyczną"8. Magdalena Marszałek zwracała uwagę na to, że oprócz „geopoetycznej lektury” istnieje równoprawnie "geopoetyczna literatura" ${ }^{\prime}$, Edward Kasperski wskazywał na istnienie oprócz „geopetyki teoretycznej" także geopoetyk: postulowanej i immanentnej ${ }^{10}$. W tej sytuacji

6 Geopoetyka wybiórczo korzysta z poststrukturalistycznych teorii, spośród których np. te podkreślające "tekstowość" nie mogłyby zostać uruchomione w kontekście wspomnianych trybów rozumienia terminu. Zob. uwagi na temat geopoetyki po strukturalizmie oraz poststrukturalizmie: E. Kasperski Geopoetyka. Ku nowej poetyce przestrzeni - pierwszy krokw chmurach..., w: Geografia wyobrażona regionu...

7 Zob. tamże, s. 30-36.

8 O. Weretiuk Próba określenia i uporzq̨dkowania znaczeń zwiq̨zanych z geopoetykq " Porównania” 2013 vol. XII, s. 26-28.

9 M. Marszałek Rosyjska Północ jako punkt widzenia , "Rocznik Komparatystyczny” 2011 nr 2, s. 104. 
stanowisko Elżbiety Rybickiej jest swoistą ucieczką do przodu: konstatując fakt „przemieszczania” się geopoetyki „pomiędzy praktykami literackimi i naukowymi dyskursami" (GP, 120), badaczka - ponad własną definicją dziedziny - ustanawia geopetykę strażniczką tych (i innych) cyrkulacji, bo przecież nie idzie tu już o refleksję dotyczącą związków literatury i przestrzeni (to tylko jeden z aspektów podejmowanych działań), ale raczej związków dwóch typów literatury: pisarstwa beletrystycznego i naukowego. Tym samym definicja ta została zrelatywizowana zarówno względem przedmiotu zainteresowania, jak i innych, konkurencyjnych ujęć („Fakt, iż geopoetyka jest pojęciem-w-działaniu znaczy również, [...], że nie ma kanonicznej, obowiązującej wykładni geopoetyki, przynajmniej na aktualnym etapie", GP, 92).

Nie oznacza to pozbycia się kłopotu, przedstawianego często jako zaleta, dodatkowa możliwość. To, co w obrębie scjentystycznego dyskursu stanowiłoby istotną przeszkodę, staje się na gruncie szeroko rozumianej poetyki założeniem zmierzającym w stronę bardziej wszechstronnego rozumienia problemów przestrzennych i „kreatywnego” podejścia do tych zagadnień. Zatem, po pierwsze: „z faktu, że geopoetyka może być cechą twórczości (a więc przedmiotu), jak i metodą interpretacyjną wynika też jej nieco chybotliwe usytuowanie - pomiędzy pojęciem a podejściem, jakkolwiek to właśnie labilna pozycja sprawia, iż jej potencjał pojetyczny się rozszerza" (GP, 91). Po drugie: narzędzia badawcze geopoetyki również mają chwiejny status, bo są nieustannie definiowane „na nowo”, wszak „metody są raczej konsekwencją praktyki badawczej" (GP, 117-118). Po trzecie: jeśli interesująca nas dyscyplina funkcjonuje jako „poetologia” (GP, 95), to wiąże się jeszcze mocniej z sytuacyjnymi, indywidualnymi punktami widzenia i tworzy sieć częściowo konkurencyjnych a częściowo uzupełniających się (nietworzących jednolitej konstrukcji myślowej) wykładni wyjściowego terminu, co powoduje, że jakiekolwiek próby wprowadzenia systematyki i normatywizmu skazane są z góry na porażkę.

W praktyce dynamiczne pojmowanie „metody” może oznaczać (i często oznacza) przejmowanie formuł nieostrych, poruszanie się w obrębie różnych znaczeń tego samego pojęcia i w obrębie różnych ich konfiguracji, słowem: dialog prowadzony w różnych językach. Koncepcje i formuły są rezultatem przenikania się eseistycznego i naukowego trybu eksplikacji poszczególnych zagadnień, co nie byłoby oczywiście niczym niedopuszczalnym, pod warunkiem że skłonność do tych nieostrych formuł nie zdominuje geopoetyckiego dyskursu. Narażony jest on bowiem na fascynację inspirującymi metaforami i twierdzeniami niezweryfikowanymi jednak sugestywnie sformułowanymi. 
Jeżeli ta inspiracja poprzedza refleksję teoretyczną, to z czasem „wędrujące” pojęcia nabierają niepokojąco rozbieżnych znaczeń, a ich potencjał poetycki zaczyna wyraźnie górować nad "geopoetyckim", eseistyczny język literatury pięknej staje się eseistycznym językiem literatury naukowej, rezygnującej z weryfikacji sugestywnych czy efektownych formuł choćby na gruncie postulowanych w kontekście geopoetyki badań interdyscyplinarnych, gdzie narzędzia odległych od literaturoznawstwa (dodatkowo uwikłanego w często dyskusyjne koncepcje kulturoznawcze) dziedzin bliskich sferze "geo" mogłyby dyscyplinować wywód. „Twórczy” potencjał geopetyki może więc prowadzić do nader swobodnego wędrowania po manowcach wiedzy tyleż efektownej, co nieefektywnej.

Kolejną ważną kwestią w kontekście funkcjonowania interesującego nas terminu jest szeroko podnoszony postulat interdyscyplinarności. Wydawałoby się, że kluczowym zabiegiem byłoby tu uzgodnienie, między jakimi sferami zachodzi interakcja badawcza. Z pozoru zostały one wskazane w złożeniu „geo" i „poiesis", lecz sprawa nie jawi się jako prosta. Wszakże biegun "geo" został zredukowany - przynajmniej w obrębie dominującego nurtu - do wybranych sfer, tzn. do geografii humanistycznej i kulturowej"1. Te zaś w dużej mierze inspirowane są przez literaturoznawstwo i kulturoznawstwo, natomiast możliwość wspomagania przez nie literaturoznawstwa jest bardzo ograniczona. Sama kategoria "miejsca” (w licznych mutacjach), choć ważna, nie wyznacza klarownych obszarów pola działania, że nie wspomnę o nieostrości owej kategorii względem pojęcia „przestrzeni”. Wybiórczość w potraktowaniu badań geograficznych wynika oczywiście z apriorycznych założeń i podstaw myślowych tak definiowanej geopoetyki, która nie wiedzieć czemu odrzuca wszystko, co pachnie „indywidualizmem”, „monadyzmem” i ,atomistycznym rozumieniem rzeczywistości” na rzecz „immanencji, stawania się, różnorodności i nieskończoności"12. Zostawmy jednak na boku skrajności zaplecza myślowego i załóżmy, że to wyłącznie nieesencjalistyczne stanowisko jest konsekwentnie realizowane: prowadzi to do "poetyzowania” sfery "geo" i do wyraźnej dominacji kulturowych komponentów „wiedzy”.

Nie jest to jedyny problem związany z interdyscyplinarnością, bo oprócz wybiórczo potraktowanej sfery "geo" w obrębie szeroko pojętej humanistyki

11 "[...] potencjalne krzyżowanie perspektyw i szukanie stref kontaktu pomiędzy humanistyką a geografią ma charakter selektywny i w szczególności dotyczy przede wszystkim geografii humanistycznej i kulturowej" (GP, s. 80-81). 
pojawiają się: historia, antropologia, socjologia, filozofia, politologia, antropologia miejsca, teoria afektów, teoria nowych mediów, kartografia krytyczna, kulturowa historia podróżowania czy kulturowa historia czytania. Z kolei tam, gdzie wkracza sfera poiesis, mamy do czynienia z całą obszerną dziedziną badań szczegółowych: topotropografia, toponomastyka, retoryka, dialektologia, antropologia lingwistyczna, poetyka odbioru, genologia, sonotopografia, osmotopografia, geokrytyka, semiologia, imagologia terytorialna, badania regionalistyczne, komparatystyka, psychologia i psychoanaliza, teorie gender, badania postkolonialne.

Nie obejdzie się tu też bez inspiracji XX-wiecznych, które powracają $\mathrm{w}$ rozmaitych przebraniach, począwszy od Bachtinowskiego pojęcia chronotopu, poprzez fenomenologiczne ujęcia przestrzeni, a skończywszy na hermeneutyce. Pytanie o poziom kompetencji badawczych we wszystkich tych dziedzinach i swobodę poruszania się w obrębie teorii nasuwa się nieuchronnie i nie pozwala przejść do porządku dziennego nad mechaniką działań, które prowadzą najpierw od nader swobodnego potraktowania przestrzeni geograficznej, o której wiedza ulega skompresowaniu ku badaniom literackim, które z kolei grzęzną w kontekście badań kulturowych potraktowanych - w konfrontacji z profesjonalnymi narzędziami nauk społecznych - równie powierzchownie. Przywołany wyżej zestaw „metod” obrazuje też inny kłopot: możliwą przewagę rozważań teoretycznych, odwołujących się do różnych ujęć nad praktycznymi zastosowaniami owych ujęć. O ile mamy do czynienia z zarysowanym obszarem badań, o tyle dałoby się wskazać niewiele ciekawych realizacji założeń teoretycznych ${ }^{13}$. Dzieje się tak zapewne dlatego, że część refleksji sięga do „tradycyjnych” sprawdzonych trybów opisu dzieła literackiego, inna zaś część „rozmywa się” w przestrzeni już nie geograficznej, lecz dyskursywnej, w której nakładają się na siebie języki definiowane przez zestaw terminów wiodących we współczesnych badaniach kulturowych. W tej sytuacji racjonalnym działaniem wydaje się wyznaczenie przez autorkę wielokrotnie tu przywoływanej książki - fundamentalnej jako punkt odniesienia dla badań "geopoetyckich" - pola wyznaczanego przez kartografię literacką (i kartografię krytyczną), geokrytykę i grupę metod „z pogranicza hermeneutyki i badań literackich, historycznych, geograficznych

Do wyjątków należą: książka Elżbiety Rybickiej, artykuły Macieja Dajnowskiego, Elżbiety Konończuk i seria wydawnicza Nowy regionalizm w badaniach literackich, choć znakomita większość prac powstałych w obrębie tego projektu w nikłym stopniu realizuje teoretyczne założenia "geopoetyki". 
czy antropologicznych" (GP, 119-120). Szczególnie ów ostatni kierunek wydaje się prowadzić ku obiecującym rezultatom, mimo że narażony jest na nieostrość eseistycznych formuł. Wszystkie one są zaś w stanie zapobiec myśleniu o geopoetyce jako sferze zdominowanej przez kulturoznawstwo kosztem jej literaturoznawczych korzeni.

Zasadnicza wątpliwość wiąże się jednak ze splotem geografii, badań literaturoznawczych i samej literatury dostarczającej inspiracji poprzez metarefleksję przestrzenną. Nie widzę przeszkód, by podejście interdyscyplinarne stało się faktem, pod warunkiem że kompetencje geograficzne badaczy będą wystarczające. Parodoksalnie, o uwzględnienie w większym stopniu owej części „geo" apelował White i jego następcy spod znaku ekokrytyki. Przesunięcie zainteresowania na "miejsce, konkret geograficzny” i przyjęcie „perspektywy bio/geocentrycznej" (GŚ, 45) musi bowiem owocować wkroczeniem w rzeczywistość dziedzin niemających nic wspólnego z literaturoznawstwem. Jak zatem przekroczyć barierę dzielącą owe sfery, nie redukując żadnej z nich do uproszczonej postaci umożliwiającej dialog ani nie doprowadzając do całkowitego ich rozejścia się? Pozostawmy to pytanie otwarte, sygnalizując jedynie, że o ile trudno mówić „o dialogu humanistyki z geomorfologią, meteorologią, oceanografią" (GP, 80), to jakaś forma jej dialogu z geografią fizyczną, historyczną, demografią czy kartografią jest możliwa i konieczna. W przeciwnym razie punktem wyjścia dla rozważań geopoetyckich mogą być takie założenia jak uczynienie z mapy wyłącznie „instrumentu wiedzy-władzy" (GP, 150), czy też preferowanie topografii jako horyzontalnego ujęcia rzeczywistości „od wewnątrz" w przeciwieństwie do rzekomo totalistycznego ujęcia „z zewnątrz" i „z góry” cechującego kartografię. W takich ujęciach często mamy do czynienia z praktyczną demonstracją niewiedzy. W związku z tym problematyczne wydają się twierdzenia o zasypaniu przepaści między naukami ścisłymi i humanistyką. Owszem, w obrębie „nowej humanistyki” podejmowane są próby, jak pisze Ryszard Nycz, „kładzenia mostów” „,w miejsce murów" dzielących tę dyscyplinę nie tylko od wspomnianych nauk, ale również od sfery techniki, życia społecznego i polityki, środowiska przyrodniczego czy sztuki i praktyk artystycznych ${ }^{14}$, lecz konkretne rezultaty takich działań nie wydają się zadowalające.

14 R. Nycz Nowa humanistyka, s. 24. Geopoetyka nie mieści się bez reszty w żadnym z wyróżnionych przez badacza "nurtów" nowej humanistyki, co wskazuje na rozmywanie się materii jej badań w obrębie humanistyki zaangażowanej, kognitywnej, posthumanistyki, i kulturowej teorii literatury. 
Docieramy tym samym do trzeciej kwestii związanej z problematycznym statusem geopoetyki. Rybicka pisze o czterech aspektach tej „orientacji badawczej": poetologicznym, geograficznym, antropologicznym i performatywnym. Relacją między pierwszymi dwoma zajęliśmy się wyżej, oddzielnego komentarza wymaga ten ostatni, niezwykle istotny, ponieważ ciągle podkreślany jako warunek konieczny funkcjonowania badań, dla których podstawowym zagadnieniem są kwestie interakcji, działania, sprawczości, nie zaś dzieła literackiego jako gotowego wytworu, wreszcie: świadomość, performatywności wszelkiego przedstawienia"15. Aprioryczne założenie owej performatywności ${ }^{16} \mathrm{w}$ obrębie dziedziny, która powinna negować wszelką aprioryczność, stanowi istotną przeszkodę na drodze rozwoju geopoetyki, choć bywa przedstawiane jako szansa. W ujęciu ekokrytycznym, które programowo odżegnuje się od geopolitycznych kontekstów, mamy wręcz do czynienia z paradoksalnym zawęźleniem; performatywizm uważany jako jeden z ważnych elementów nowej humanistyki zdradza wyraźne zaplecze ideologiczne, a krytyka w obrębie tak pojętej geopoetyki przestaje być analizą i staje się pracą „na rzecz zmiany w świecie” (GŚ, 17). Nawet dość wąskie pojmowanie „polityczności” mieści w sobie wyraziste deklaracje rzekomo abstrahujących od niej działań: „Humanistyka ekologiczna to także budowanie wspólnej przestrzeni dla buntów i rewolucji, przede wszystkim na rzecz planety, ale nie tracąc z oczu jej mieszkanek i mieszkańców, ludzi i nie-ludzi" (GŚ, 17). W konsekwencji lektura tekstów literackich zmienia się w ich weryfikację pod kątem obecności postulatywnych założeń, jakie powinno spełniać dzieło, by można było uznać je za posiadające „potencjał wywrotowy”, co prowadzi do doktrynerstwa i szeregu wykluczeń dotyczących nawet pisarstwa tematycznie ukierunkowanego i będącego przedmiotem zainteresowań inaczej zorientowanej geopoetyki" ${ }^{17}$.

Podobnie w przypadku wspomnianego antropologicznego aspektu geopoetyki: „Antropologiczna strona koncentruje się natomiast na relacjach między podmiotem a przestrzenią geograficzną. Z tego powodu kluczową kwestią będzie tu doświadczenie zmysłowe i emocjonalne reakcje prowadzące do literackiej geografii sensorycznej, geografii emocji i topografii emotywnych" (GP, 107). Nie widzę powodu, dla którego geopoetyka nie miałaby zajmować się racjonalnym ujęciem miejsca i przestrzeni w tekście literackim i wszelkimi innymi dyspozycjami poznawczymi podmiotu.

17 Normatywizm ekokrytycznego stanowiska ujawnia się w książce Anny Kronenberg. Właściwie żadna twórczość literacka (poza twórczością Kennetha White'a) nie jest w stanie sprostać założeniom perspektywy definiowanej (niezbyt precyzyjnie zresztą) na płaszczyźnie tematycznej, , formalnej" i „światopoglądowej”. 
W głównym nurcie refleksji geopoetyckiej aspekt performatywności pojmowany jest inaczej, jako "przekonanie, że literatura performatywnie powołuje, kreuje i nadaje znaczenia przestrzeni" (GP, 46), przy czym owa kreacja została ujęta w ramy specjalistycznych dyskursów opisujących „politykę miejsca": refleksji nad językiem, geografią wyobrażoną, historią rewindykacyjną (polityką pamięci) i literackimi aktami konstytuującymi wspólnotę doświadczenia we wspólnej przestrzeni geograficzno-kulturowej. Kluczowa jest w tym kontekście deklaracja Elżbiety Rybickiej, która definiując nastawienie badawcze, wskazuje na niebezpieczeństwa z nim związane: „Na szczególne rozważenie zasługuje kwestia przejścia od poetyki przestrzeni do polityki miejsca, ponieważ może ona budzić największy opór. O ile w zachodnich dyskursach humanistycznych jest sprawą aż nadto oczywistą, o tyle w naszym, lokalnym kontekście polityka i ideologia to ciągle egzorcyzmowane upiory polskiej humanistyki akademickiej.Z drugiej strony jednak, uwikłanie literackich reprezentacji przestrzeni we władzę jest problemem oczywistym, choć od razu trzeba dodać, że i niezwykle podatnym na banalizację i nadmierne rozszerzania" (GP, 53-54).

Jeżeli wspomniane przejście, umieszczane w kontekście różnorakich zwrotów, budzi mój opór, to nie dlatego, że polityka, historia, ideologia postrzegane są przeze mnie jako „upiór", raczej wręcz przeciwnie: jako bardzo żywy i nadto ekspansywny organizm dążący do zawłaszczenia terytorium np. estetyki. Jej autonomiczny status wydaje się nie do utrzymania, ale - jak zauważa cytowana autorka - „uwikłanie we władzę” (które w przypadku wielu utworów wcale nie wydaje się oczywiste) jest jednym z aspektów owej ekspansywności i banalizuje refleksję badawczą, nadto akcentując „demaskatorski” tryb odczytywania tekstów kosztem wszystkich innych aspektów lokowania przestrzennego ignorującego symboliczne czy retoryczne struktury władzy.

O ile więc - z dzisiejszej perspektywy - poetyka przestrzeni, pojmowana tak jak w tekście Sławińskiego sprzed lat bez mała czterdziestu, nie wydaje się atrakcyjną propozycją, o tyle atrakcyjność „polityki miejsca” jako performatywnie i nomadycznie zorientowanej inspiracji geopoetyki wydaje się niewystarczającą zachętą do poszukiwania wszechstronnych ujęć problematyki przestrzennej w literaturze. Nie ma w tym sformułowaniu pomyłki: w obrębie geopoetyki winno bowiem znaleźć się miejsce także dla refleksji skupiającej się na literaturze, która niekoniecznie musi służyć, wedle sformułowania Greenblatta, „zrozumieniu kultury”. Albo też inaczej, pozwala ona dobrze rozumieć kulturę także poprzez uruchomienie innych trybów dyskursu niż 
teorie kulturowe czy „topoanaliza kulturowa” (GP, 118). Nie chodzi tu wyłącznie o konserwatywnie nastawionych badaczy, równie dobrze można byłoby mówić o kaprysie metodologicznym stawiającym na rozkosz lektury pozbawionej niektórych aspektów performatywnego nastawienia. Zostawiającej na marginesie dużą część praktyk kulturowych związanych z miejscem (szlaki literackie, festiwale, travelblogi), jako mało ważnych z punktu widzenia istoty relacji zachodzących między aktem twórczym a miejscem/przestrzenią. Daleki jestem od ignorowania tych zjawisk, upominam się raczej o prawo selekcji i hierarchizacji przedmiotów zainteresowania.

Przywołane tu koncepcje geopoetyki wychodzą z jasno sformułowanych założeń i - szczególnie w przypadku książki Rybickiej - stanowią spójną, autorską propozycję, nie w tym rzecz zatem, by postulować radykalne zmiany w ich obrębie. Idzie raczej o artykulację problematyczności pewnych tez w zderzeniu z pożądaną efektywnością praktyk interpretacyjnych abstrahujących od uwarunkowań wewnątrzliterackich. Nie można bowiem dokonać korekty założeń geopoetyki przy użyciu narzędzi poetyki, ponieważ postulowana praktyka badawcza ma prowadzić ku „zmianie myślenia o literaturze" (GP, 370), ku ukazywaniu przede wszystkim jej „działania” w obiegach kulturowych i sprawczych potencji samego procesu twórczego. Refleksja literaturoznawcza wkracza tu na obszar, który lepiej poddawałby się trybowi analiz kulturoznawczych.

Performatywność geopoetyki prowokuje też postawienie pytań szczegółowych, np. o przedmiot jej zainteresowań. Elżbieta Rybicka wskazała, jaki „typ" literatury stanowi istotny punkt odniesienia dla badacza podejmującego wyzwanie zdefiniowanej przez nią orientacji. Tym samym dokonało się wykluczenie sporego obszaru literatury, mimo że w zamyśle teoretycznym widoczne jest dążenie do poszerzenia pola obserwacji, nawet w przypadku tak "niegeograficznych” pisarzy jak Witkacy czy Gombrowicz. Co innego natomiast praktyka badawcza w momencie, gdy przechodzimy do bardziej rozbudowanych tekstów analitycznych, skoncentrowanych głównie na twórczości, która sama podsuwa tropy topograficzne, takiej jak książki Andrzeja Stasiuka, Mariusza Wilka czy olbrzymi obszar literatury regionalnej/regionalistycznej i podejmującej tematy tożsamości lokalnej, pamięci, granic, peryferii. Szczególnie badania dotyczące tej ostatniej są imponującym przedsięwzięciem, co jednak nakazuje zauważyć fakt performatywnego nastawienia samej orientacji geopoetyckiej kreującej skalę i zasięg interesujących ją zjawisk.

Wróćmy jeszcze do równie istotnej kwestii regionalizmu. Praktyczne rozbudowanie tego "działu" geopoetyki oznacza performatywność w wymiarze 
opisu ciągłego tworzenia się regionu, ale też „tworzenia regionu”; nowa perspektywa kulturowa daje do rąk badaczy narzędzia, które zdają się całkowicie ignorować podejście przeciwstawne, tzn. wymiar obiektywnego istnienia regionu, punktu wyjścia, który - niekoniecznie wyłącznie w obrębie „staroświeckich" metodologii - determinuje ową dynamiczną konstrukcję myślową, domagającą się obecności nie tylko „badań antropologiczno-kulturowych, komparatystyki, badań postzależnościowych i postkolonialnych, geopoetyki, etnopetyki, humanistyki nie-antropocentrycznej" (GP, 347), ale wciąż - geografii, historii, historii sztuki i architektury, a także wielu innych dziedzin wiedzy. Nie idzie tu - podkreślam - o cofanie badań na poziom regionalistyki XX-wiecznej, której mielizny niejednokrotnie już wskazywano. Jednak niebezpieczeństwo przyłożenia do kwestii literatury regionów wyłącznie matryc aktualnie obowiązującego języka nie zawsze musi przynieść korzystne rezultaty. Jak pisał Zbigniew Chojnowski: „Efekty badań literaturoznawczych wynikających ze zwrotu topograficznego wyposażają literaturoznawstwo regionów we wciąż poszerzający się zestaw narzędzi. Wszystkie one mogą być zastosowane. Ale literaturoznawcę regionów od badacza geopoetyki powinna odróżniać inaczej nastawiona świadomość, która nakazuje uwzględniać zanurzenie dzieła literackiego w geograficzno-kulturowe pokłady regionu oraz formy i funkcje zespolenia z nim"18.

Jak się wydaje, perspektywa badawcza geopoetyki nie jest różna od nastawienia badacza literatury regionów, a raczej nie byłaby różna, gdybyśmy brali pod uwagę przede wszystkim literaturę „w kontekście”, nie zaś kontekst, który literatura buduje, jako praktyka performatywna, stając się częścią różnorodnych działań, dla których - nawet przy użyciu narzędzi nauk społecznych trudno znaleźć wspólny mianownik. Pytanie, czy zatrzymamy się na tezach Greenblatta, czy spróbujemy bardziej zróżnicować przestrzeń wspomnianych badań na rzecz dowartościowania czynnika „wewnątrzliterackiego”, jest pytaniem zasadniczym, pytaniem o metodologiczny, ale też aksjologiczny $i$, last but not least, estetyczny horyzont geopoetyki. Nierównowaga, jaka teraz panuje, każe wciąż upatrywać choćby w nowym regionalizmie swojego rodzaju antidotum na dotychczasowe niedomagania tego typu badań („Można odnieść wrażenie, że badania regionalne czekały na otwierającą się dziś perspektywę, która realizuje od dawna podnoszony postulat «uwolnienia od wartościowania». Przy czym w możliwościach, jakie dla badań regionalnych

18 Z. Chojnowski Literaturoznawstwo regionów (w poszukiwaniu skutecznych perspektyw badawczych), w: Nowy regionalizm..., s. 27. 
niesie kulturowa teoria literatury, chodzi nie tylko o zmianę hierarchii (o antycentralizm czy interakcyjną wizję zależności centro-peryferyjnych), ale o wyjście poza dotychczasowe sposoby myślenia, w stronę - [...] - nowego miejsca, z którego można by literaturę regionalną badać"19). Należałoby się zastanowić, czy zastąpienie dwóch typów dyskursu regionalistycznego owym "nowym” podejściem rzeczywiście pozwala odejść od wartościowania (przy pewnej absolutyzacji relacyjnego i dynamicznego podejścia) i czy zastąpienie badań nad „monofoniczną" utopią badaniami nad utopią opartą na polifonii jest krokiem w stronę odpowiedzi na pytanie o rzeczywiste oblicze zarówno "regionu", jak i literatury związanej z regionem i wszelkich ambiwalencji powiązanych z „przestrzennym zaangażowaniem” tekstu literackiego.

Kiedy z kolei przyjrzymy się tekstom inspirowanym zespołem tez ustanawiających geopoetykę jako narzędzie badań literackich, kłopot z praktycznym zastosowaniem „metody” stanie się jasny. Tak jak w przypadku wprowadzenia kategorii kartograficznych ${ }^{20}$ (kartografii krytycznej) będących kluczem do lektury konkretnych utworów. W takim ujęciu skądinąd znakomite analizy stają się często niemal wyłącznie narzędziem demaskowania stereotypów, dyskursów „władzy” etc. Przy czym miejsce jednego modelu mentalnego opierającego się na schematyzmie postrzegania zajmuje model inny, zdradzający również tendencje do zamykania się w obrębie ideologicznego dyskursu. Podejście to - abstrahując od indywidualnej sprawności badacza - daje w rezultacie nie opis, ale obraz ścierających się idei. O ile np. w dociekaniach Macieja Dajnowskiego dotyczących „rosyjskiej” prozy Mariusza Wilka ${ }^{21}$ mamy do czynienia ze wskazaniem, jak w tekście literackim kategorie kartograficzne przekładają się na sposób postrzegania rzeczywistości, i jedynie końcowe partie wywodu wskazują na ideologiczną postawę wpisaną zarówno w analizowany utwór, jak i badawczy wysiłek (okazuje się, że siłą napędową Wilczego notesu jest „wola polityczna” przezwyciężenia rusofobicznych, „wstrętnych” uprzedzeń), to w przypadku książki Przemysława Czaplińskiego Poruszona mapa stanowisko polityczne autora uwyraźnione zostaje już w pierwszym akapicie Wstępu, zgodnie - jak się zdaje - ze stanowiskiem odrzucającym

19 M. Mikołajczak Dyskurs regionalistyczny we współczesnym (polskim) literaturoznawstwie - pytania o status, poetykę i sposób istnienia, w: Nowy regionalizm..., s. 50. narnym dialogu geografii, historii i literatury " Teksty Drugie" $2011 \mathrm{nr} 5$. 
nieuprzedzone poznanie. Problem polega na tym, że kartografii jako inspirującego elementu sfery "geo" nie da się zredukować wyłącznie do jej potencjału krytycznego. Finezyjny wysiłek badawczo-interpretacyjny idzie w stronę nie zderzenia rzeczywistości literatury i geografii, lecz w stronę zderzenia polityki czy świata idei z literaturą i to przy znacznym zminimalizowaniu cech swoistych samej literatury, geografia i kartografia stanowią zaś jedynie rezerwuar poręcznych konceptów i metafor. Poznański badacz deklaruje wprawdzie, że inspirację metodologiczną stanowią dla niego tezy zawarte w książce Rybickiej, ale o równowadze dwóch pierwiastków nie ma w tym przypadku mowy. Z punktu widzenia "geo" mapa ujmowana jest tu metaforycznie, a ujęcie to zakłada np. uprzedniość narracji względem mapy czy zupełnie nieprzystającą do dialogu interdyscyplinarnego tytułową figurę „mapy poruszonej". Rozważania te służą celowi, który zresztą został uczciwie przez Czaplińskiego wyłożony w początkowych partiach rozważań: „Rzeczywistym przedmiotem mojego zainteresowania, prześwitującym przez nowe mapy jest samowiedza polskiej kultury"22 . Co zatem mają począć ci, dla których samowiedza polskiej kultury wymaga szerszych analiz i ci, dla których istotniejsza jest samowiedza literatury i jej zderzenie z kartograficzną (czy geograficzną) rzeczywistością niezideologizowaną?

Ciekawą propozycją w takim kontekście wydaje się artykuł Małgorzaty Czermińskiej pokazujący, jak można połączyć punkt widzenia związany z badaniami stricte literackimi i perspektywę geopoetyki. Badaczka pisze o kategorii „miejsca autobiograficznego”, wyraźnie podkreślając, po pierwsze: przy jednoznacznie zdefiniowanej, rzeczywistej relacji z materialną, będącą przedmiotem badań nauk przyrodniczych, przestrzenią - jego autonomiczny byt, to, że miejsce „istnieje jednak na innej płaszczyźnie”23, po drugie: oczywisty prymat orientacji literaturoznawczej, przy wskazaniu, że jest ona

22 P. Czapliński Poruszona mapa. Wyobraźnia geograficzno-kulturowa polskiej literatury przełomu XX i XXI wieku, Wydawnictwo Literackie, Kraków 2016, s. 9. Polemika z instrumentalnym użyciem kategorii kartograficznych wymagałaby odrębnych rozważań. Nie zamierzam natomiast wchodzić w polemikę z tezami publicystycznymi tego błyskotliwie sformułowanego wywodu.

23 "Zachowuje swoje konieczne odniesienie do miejsca geograficznego, nie jest jednak kawałkiem rzeczywistej, fizycznie istniejącej przestrzeni, ani nawet po prostu zespołem związanych z nią kulturowych znaczeń i wyobrażeń" (M. Czermińska Miejsce autobiograficzne. Propozycja w ramach geopoetyki, "Teksty Drugie” 2011 nr 5, s. 186). Podobnie w powiązaniu z "miejscem pamięci" miejsce autobiograficzne stanowi konstrukt autonomiczny, choć miewa "swoje przedmiotowe, materialne odpowiedniki topograficznie usytuowane" (M. Czermińska Miejsce autobiograficzne, s. 187). 
wciąż źródłem inspiracji zarówno dla tekstów z kręgu geografii humanistycznej, jak też z kręgu badań kulturowych ${ }^{24}$. Problem w tym przypadku stwarza pytanie, czy ów zamysł można rozciągnąć na badania relacji przestrzennych w obrębie całej literatury, czy też może on odnosić się tylko do obszaru pisarstwa autobiograficznego i tego, co zostało nazwane przez badaczkę typem wyobraźni topograficznej. Jeśli weźmiemy pod uwagę poczynione przez autorkę założenie istnienia „zbiorowego syntetycznego podmiotu dzieł wszystkich jednego autora"25, każde odniesienie przestrzenne niejako nabiera w tym kontekście indywidualnego charakteru, znosząc tym samym nachalnie performatywny wymiar geopoetyckiego ujęcia. Jeszcze inaczej rzecz ujmując, niemal zawsze możemy przyglądać się rzeczywistości tekstu związanej z rzeczywistością miejsca jako przestrzeni indywidualnie nacechowanej, niekoniecznie jednak czemuś służącej. A jako że dychotomiczny charakter typów wyobraźni (topograficznej i ignorującej topografię na rzecz świata relacji międzyludzkich) nie jest tu traktowany dogmatycznie, można próbować rozciągnąć kategorię miejsc autobiograficznych (poszerzając je o inne rodzaje doświadczenia) na większosśc świadectw literackich,jakie w ogóle mogą stać się przedmiotem uwagi badacza.

Zatrzymałem się przy tej propozycji, ponieważ sugeruje ona jeden z kierunków, w jakim podążać mogłaby geopoetyka jako subdyscyplina badań literaturoznawczych. Świadomie używam tego określenia, stojąc na stanowisku, że narzędzia wykształcone przez te badania, a często odrzucane dziś na rzecz niepogłębionych diagnoz quasi-socjologicznych czy quasi-kulturoznawczych wciąż pozwalają na wnikliwą analizę tekstów, dla których „wyznaczanie” tendencji, zarysowywanie perspektyw życia zbiorowego i przemian mentalnych jest tylko jednym, wcale nie najważniejszym, horyzontem poznawczym. Nie twierdząc, że performatywność dzieła nie odgrywa żadnej istotnej roli, coraz częściej zauważam jej istnienie bardziej jako projekcję takiegoż, performatywnego nastawienia badacza/badaczki niż jako dający się zweryfikować element definiujący tekst będący przedmiotem zainteresowania, toteż skłonny byłbym rozpatrywać raczej jego modalność i zastanawiać się, jak - przy użyciu dostępnego instrumentarium badań literaturoznawczych, dalekich od dogmatycznie pojmowanego dziedzictwa strukturalizmu - uruchomić mechanizm translacji kategorii przestrzennych na język tekstu literackiego,

\footnotetext{
24 Jak zauważa autorka cytowanego artykułu, najnowsze badania kulturowe korzystają z dorobku semiologii, fenomenologii czy badań mitograficznych. 
weryfikując fakt „bezinteresownej” (czyli nieprzekładalnej na konstrukty ideologiczne) reprezentacji miejsca czy obszaru i tworząc mechanizm weryfikacji wszystkich elementów, jakie biorą udział w owym procesie przekładu. Miejsce (czy przestrzeń) bowiem w takim samym stopniu może być kategorią estetyczną, jak polityczną, a punktem końcowym czynności jego „przyswajania" przez literaturę nie musi być projekcja ładu/bezładu społecznego, tak jak czynność kreślenia mapy nie daje się wytłumaczyć jedynie w kategoriach wiedzy-władzy.

Geopoetyka w takiej perspektywie stanowi zatem dziedzinę badań „podstawowych", przy czym nie odnosi się to do zabiegów mających dawać odpowiedź na pytanie o stopień autentyczności doświadczenia przestrzennego lub dokładności odwzorowania przestrzeni geograficznej w dziele literackim. Ma raczej odpowiadać na pytanie o układ znaczeń jaki tworzą obecności lub nieobecności tych doświadczeń i odwzorowań (miejsce w takim samym stopniu nadaje znaczenie literaturze jak ona miejscu). Wreszcie, o związki konfiguracji przestrzennych i indywidualnych światoobrazów i estetyk. Kulturowe walory konkretnego obszaru (widziane i w perspektywie synchronicznej i diachronicznej) nie muszą przy tym układać się w mniej lub bardziej oczywiste komunikaty ideologiczne; miejsca, przestrzenie, obszary są bowiem z natury zróżnicowane, a narracje związane z nimi często znoszą się wzajemnie i stanowią równie skomplikowaną sieć, jak układ elementów dzieła literackiego. To jedna z możliwości: geopoetyka "nierozproszona”, wskazująca na literaturoznawcze kompetencje jako na punkt wyjścia, abstrahująca zarówno od postmarksistowskich, jak i postpozytywistycznych ograniczeń.

Inną obiecującą sferą, w której geopoetyka mogłaby się rozgościć, byłaby przestrzeń rzeczywistego, niesymulowanego dialogu interdyscyplinarnego. To kwestia najtrudniejsza, gdyż wymagająca orientacji w dziedzinach wykraczających poza stosunkowo łatwo przyswajalny kanon pojęć i stylów lektury obowiązujących w danym momencie w obrębie szeroko pojmowanej humanistyki. Wydaje się wręcz, że bariera, jaka rysuje się między "geo" i „poiesis”, jest nie do przezwyciężenia, jeśli zrezygnujemy z pośrednictwa tych dyscyplin geografii, które zostały ukształtowane w ostatniej ćwierci minionego wieku przez język badań humanistycznych. Stanie się tak wówczas, gdy nie będziemy potrafili wykorzystać wiedzy stricte geograficznej lub kartograficznej do innych celów niż budowanie metafor. Doskonałym przykładem realizacji badań interdyscyplinarnych jest tłumaczona na język polski książka wspomnianego Karla Schlögela W przestrzeni czas czytamy, w której autor nazywa swoje dociekania służące skonstruowaniu narzędzi pozwalających 
"odnowić" warsztat historyka przez wykorzystanie kategorii przestrzennych (przy czym nie chodzi o zdominowanie przez nie badań historycznych, raczej o równouprawnienie w obrębie „czasporzestrzeni” ${ }^{26}$ ) historiografią topocentryczną lub hermeneutyką topograficzną. I mimo że znajdziemy tu wiele odwołań do problematyki „zwrotu przestrzennego", badań w obrębie geografii humanistycznej czy refleksji Edwarda W. Soji, to mamy także do czynienia z konstatacją dystansu wobec zadekretowanych kierunków przedsięwzięć naukowych („Deprecjacja dyskusji o turn ma też tę dobrą stronę, że podminowuje i ironizuje z roszczeń do wyjątkowości i wyłączności. To dobrze"27). Podobna ambiwalencja cechuje spojrzenie Schlögela na kwestię uwikłań politycznych geografii i mapy. I choć pisze o geopolityce, czy wskazuje na swojego rodzaju prekursorstwo Yi-Fu-Tuana oraz Henriego Lefebvre'a i jego teorii „produkcji przestrzeni społecznej”, to jednocześnie wskazuje na... brak genealogii badań przestrzennych, na ich "wyspowy" i indywidualistyczny rys, wreszcie, na autonomiczność samego pojęcia przestrzeni („Przestrzeń jest skolonializowana przez pojęcia z nauk społecznych. Teraz chodzi o to, by dopuścić ją do siebie w całej jej niesamowitości”28).

Jak się wydaje, literaturoznawstwo również powinno dopuścić do głosu przestrzeń wraz z jej niesamowitością i skonfrontować własne narzędzia badawcze nie z kulturoznawczymi formułkami, lecz z emanacjami przestrzeni, np. z miejscem, które - jak pisze Schlögel - jest „ucieleśnieniem złożoności". Bowiem, zdaniem badacza, przestrzeni nie da się opowiedzieć, a teza ta wchodzi na pewnym poziomie w kolizję z twierdzeniem o ideologicznym, narracyjnym charakterze postrzegania czy też o takim właśnie zapleczu map i władzy z nimi związanej, a także o wszelkich innych właściwościach dyskursu mających charakter performatywny. Przy czym nie poprzestaje się tu na takich twierdzeniach, równie ważny jest aspekt estetyczny, kolekcjonerski etc., zaś ujęcia przestrzeni są jednakowo ważne, niezależnie od stopnia zaawansowania techniki tych ujęć, i,zamknięte w sobie, logiczne, wewnętrznie zrozumiałe”29. Inspirująca (ale też często „wewnętrznie sprzeczna”) książka

"[...] nie ma piękniejszego słowa w naszym języku" - pisze niemiecki badacz o związku temporalnych i spacjalnych determinant poznania (K. Schlögel W przestrzeni czas czytamy. O historii, cywilizacji i geopolityce, przeł. I. Drozdowska, Ł. Musiał, Wydawnictwo Poznańskie, Poznań 2009, s. 67). 
niemieckiego badacza wskazuje zatem powtórnie na autonomię dziedzin i konieczność ich bezpośredniej konfrontacji. Być może najlepiej takie podejście sprawdzałoby się w przypadku pisarzy, którzy mogliby powiedzieć: „Nie mam nic do powiedzenia; tylko do pokazania"30. Znamienne, że ten punkt widzenia artykułowany jest w trybie w dużej mierze eseistycznym, bowiem właśnie on daje możliwość wprowadzenia elementów wiedzy nienależącej (w tym wypadku) do dyskursu badań historycznych.

Zadaniem zatem geopoetyki jest również powtórne przyjrzenie się „językowi" przestrzeni i mapy; nie istnieje on poza regułami, których obecność można zauważyć i w obrębie języka literatury. Przenikanie się owych języków zyskuje rozmaite postacie i uwypuklenie tylko jednej z nich stanowi akt sprzeniewierzenia się rzetelności badawczej. „Literaturoznawstwo topocentryczne” mogłoby stanowić istotną część sztuki interpretacji; „oglądałoby” dzieło, tak jak się ogląda i rozszyfrowuje mapę - sięgając nie tylko do wiedzy o wspomnianych regułach, ale też do wszelkich kontekstów, podsuwanych przez znaki na mapie. Byłoby dowodem żywotności humanistyki, która nie lęka się wyjścia poza własne terytorium, co stałoby się możliwe także dzięki intensywności dialogu wewnątrz niej, pozbawionego jednak „strategicznych planów" i dominacji metod, które chcąc tropić wszelkie wykluczenia, same mogą wykluczyć oryginalność pojedynczych, „peryferyjnych” z pozoru, odczytań. 


\section{Abstract}

\section{Andrzej Niewiadomski}

MARIA CURIE-SKŁODOWSKA UNIVERSITY (LUBLIN)

What Is "Geopoetics" and What Else Could It Be?

Outlining various attempts at codifying geopoetics as a trend in Polish literary scholarship Niemiadomski highlights two definitions revolving around ecocriticism and cultural theory of literature. He then points out the problems that come with current definitions: issues related to the status of the discipline being in flux, the risks that come with adapting in practice the postulate of performativity as an essential quality of geopoetics, as well as the problems arising from a narrow understanding of interdisciplinarity. Niewiadomski then proposes to treat geopoetics as a sub-discipline of literary scholarship rooted in a meaningful dialogue with the methods that geographers and cartographers developed to describe places and spaces.

\section{Keywords}

geopoetics, ecocriticism, new regionalism, cultural theory of literature, space in literature, new humanities 